\title{
腎移植後感染症の臨床的検討
}

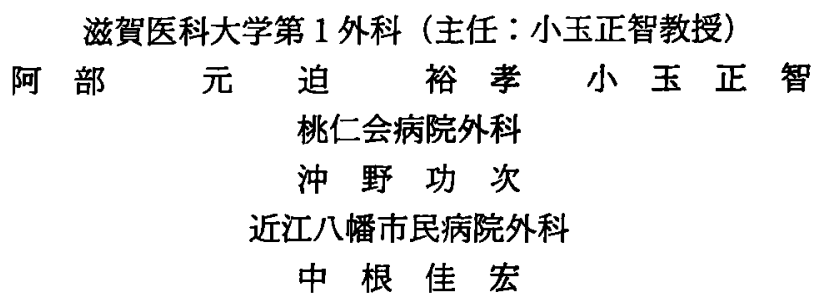

1982年 7 月から1994年 6 月までに施行した腎移植症例66例(生体腎33例，死体腎33例） を対象に，移植後感染症について臨床的検討を行った。66例中23例（35.3\%）に計26回 の感染症がみられた. 免疫抑制法別では azathioprine (AZ) と prednisolone (PD) 症 例の11例中 5 例 (45.5\%), ciclosporin (CYA) と PD 症例の22例中 9 例 (40.9\%), CYA, $\mathrm{AZ} ， \mathrm{PD}$ の 3 剂併用例の33例中 9 例 (27.3\%) に感染症がみられた。肺感染症 9 例，帯 状疮疹 9 例, 脳髄膜炎 2 例, 出血性膀腅炎 3 例, 創部感染 2 例, 眼球感染 1 例であり, 感染症死は 4 例であった。この内17例（65.4\%）が移植後 $1 \sim 6$ 力月に集中していた. 病原体はウイルスが17例, Pneumocystis carinii 4 例, 細菌 3 例, 真菌 2 例であった. 生体腎と死体腎症例では発生頻度に差はなかったが, 死亡例は死体腎に多い傾向を認め た. 急性拒絶反応は感染群に多い傾向がみられた。臨床検查值では感染群で血清アルフ ミン值の低下と IgG 值の激隇がみられた。腎移植後感染症は PD の使用量と拒絶反応の 有無に関連し，血清アルプン值とIgG 值が指標となると考えられた。

索引用語：堅移植, 感染症, 予知因子

\section{績 言}

腎移植に ciclosporin (CYA) 等の新しい免疫抑制郕 が使用されるようになってから，その生着率は飛躍的 に向上したが，術後感染症は移植後合併症における死 因の第 1 位を占めており"2，その対策が不可欠である。 今回われわれは滋賀医科大学にて施行された腎移植症 例を対象に，腎移植後感染症について臨床的検討を 行ったので報告する。

\section{対 象}

1982年 7 月から1994年 6 月までに滋賀医科大学で施 行した腎移植症例は66例で，生体腎33例，死体堅33例 (再移植例 1 例)を対象とした。腎移植症例66例中23例 (35.3\%)に計26回の感染症がみられ，これらを感染群 として非感染群43例と比較検討した。

免疫抑制法2 は，1986年までは azathioprine (AZ)， prednisolone (PD) の併用または CYA, PD の併用療
法を行い, 1987年以降は CYA，AZ，PDによる 3 郕併 用療法を行った (図 1). PD の使用量として, $A Z$ と PD の 2 剂併用療法では術当日より $100 \mathrm{mg} /$ day から 開始し, 以後漸減して術後30日に $45 \mathrm{mg} / \mathrm{day}, 60$ 日に30 $\mathrm{mg} / \mathrm{day}, 90$ 日に $20 \mathrm{mg} /$ day と減量し，9〜10力月後に $10 \mathrm{mg} / \mathrm{day}$ を維持量とする.CYA を用いた併用療法て は $\mathrm{AZ}$ 使用例の半量,すなわち術当日より $50 \mathrm{mg} / \mathrm{day}$ で開始し, 以後渐减して $10 \mathrm{mg} / \mathrm{day}$ を維持量としてい る.

なお, 統計学的有意差検定は Student-t 検定, $x^{2}$ 検定 を用いた。

1）背景因子

$$
\text { 結果 }
$$

非感染群と感染群との背景因子をみると, 移植時年 齢，透析期間，䚘前輸血量に有意差を認めなかったが， 性別では感染群に男性の比率が多かった（表 1 ）。

2）免疫抑制法

感染症の発生は, $\mathrm{AZ}$ と PDによる 2 剂併用療法の 
A.
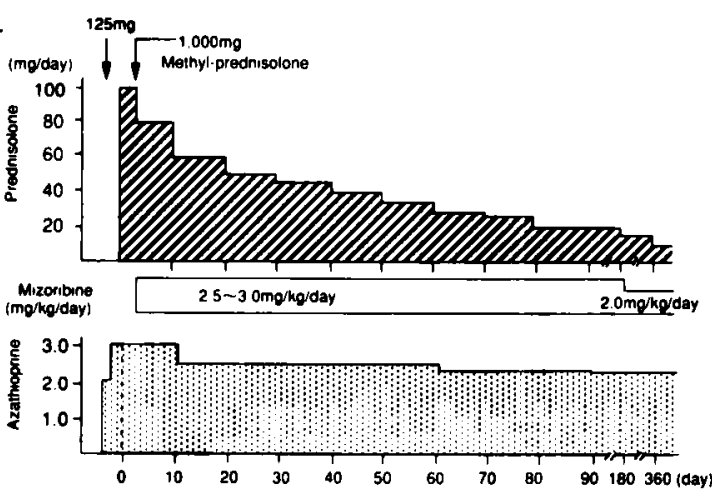

B.
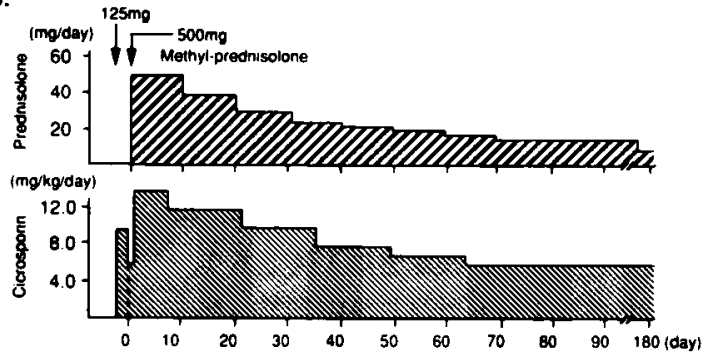

c.
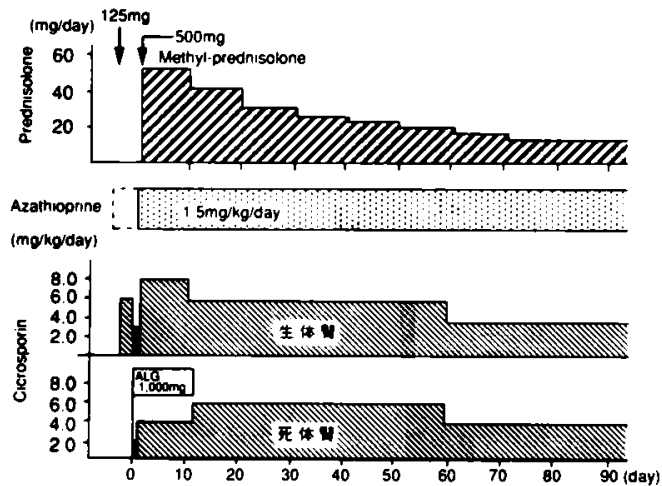

図 1 免疫抑制法

$\mathrm{A}: \mathrm{AZ}$ と $\mathrm{PD}$ の併用療法, B : CYA と $\mathrm{PD}$ の併用療 法, C：CYA，AZ，PD 03 剂併用療法

11例中 5 例 $(45.5 \%), \mathrm{CYA}$ と PD の 2 剂併用が 22 例 中 9 例 $(40.9 \%), \mathrm{CYA}, \mathrm{AZ}, \mathrm{PD}$ の 3 剤併用が33例中 9 例 (27.2\%) であった。CYA およびPDの使用量が 少ない 3 剂併用法で発生率が減少していた（表 2 ）.

\section{3）発生部位，時期}

感染症の発生部位は, 肺感染症 9 例, 带状疮疮 9 例, 骮有膜炎 2 例, 出血性膀腅炎 3 例, 創部感染 2 例, 眼球 感染 1 例であった。生体堅, 死体腎移植症例による発 生率に差はなかったが，死亡例は肺感染症が 3 例，髄 膜炎が 1 例で，死体腎移植症例に多かった（表 3 ）.
表 1 非感染群, 感染群の背景因子

\begin{tabular}{|c|c|c|c|c|}
\hline & & $\begin{array}{c}\text { 非感染群 } \\
(\mathrm{n}=\mathbf{4 3})\end{array}$ & $\begin{array}{c}\text { 感 染 群 } \\
(\mathrm{n}=23)\end{array}$ & $\mathrm{P}$ \\
\hline \multicolumn{2}{|c|}{ 移植時年龄 (歳) } & $33.8 \pm 11.4$ & $31.4 \pm 11.4$ & N.S. \\
\hline \multirow{2}{*}{ 性 別 } & $\S$ & 26 & 17 & \multirow{2}{*}{$p<0.05$} \\
\hline & q & 16 & 6 & \\
\hline \multicolumn{2}{|c|}{ 透析期間 (月) } & $35.9 \pm 31.3$ & $44.0 \pm 39.7$ & N.S. \\
\hline \multirow{3}{*}{$\begin{array}{c}\text { 術前輸血量 } \\
(\mathrm{ml})\end{array}$} & $\leqq 400$ & 16 & 7 & \multirow{3}{*}{ N.S. } \\
\hline & $\leqq 1,000$ & 15 & 8 & \\
\hline & $>1.000$ & 8 & 5 & \\
\hline
\end{tabular}

表 2 免疫抑制法による発症率

\begin{tabular}{c|c|c}
\hline & 症例数 & 感染症例(\%) \\
\hline $\mathrm{AZ}+\mathrm{PD}$ & 11 & $\mathbf{5}(45.5) *$ \\
$\mathrm{CYA}+\mathrm{PD}$ & 22 & $\mathbf{9 ( 4 0 . 9 )}$ \\
$\mathrm{CYA}+\mathrm{AZ}+\mathrm{PD}$ & 33 & $\mathbf{9 ( 2 7 . 3 ) *}$ \\
\hline
\end{tabular}

AZ: Azathioprine PD: Prednisolone CYA : Ciclosporin $\quad(*: p<0.05)$

表 3 感染症の発症部位

\begin{tabular}{|c|c|c|c|}
\hline & 生体堅 & 死体䁚 & 計 \\
\hline 眠感染症 & 3 & $6(3)$ & 9(3) \\
\hline 帯状疱胗 & 5 & 4 & 9 \\
\hline 葡膜炎 & $2(1)$ & & 2(1) \\
\hline 出血性膀睄炎 & 3 & & 3 \\
\hline 創部感染 & & 2 & 2 \\
\hline 眼球感染 & 1 & & 1 \\
\hline 計 & $14(1)$ & $12(3)$ & $26(4)$ \\
\hline
\end{tabular}

これら感染症のうち 16 例 (61.5\%) が移植後 1 カ月 から 6 力月まてに集中し，生体腎移植症例の平均発症

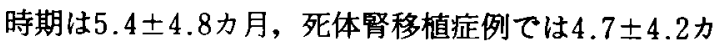
月であった (図 2 ).

4) 病原体

病原体はウイルス17例中 Herpes zoster virus ( $\mathrm{HZV}) 9$ 例, Cytomegalovirus (CMV) 3 例, Adenovirus 3 例, Herpes simplex virus (HSV) 1 例, 不明 1 例で, Pneumocystis carinii (PC) は 4 例, 細菌は Streptcoccus faecalis 2 例, Listeria 1 例，真 菌では Candida と Aspergillus が 1 例ずつであった (表 4).

5）急性拒絶反応

急性拒絶反応と感染症との関係では, 非感染群の発 


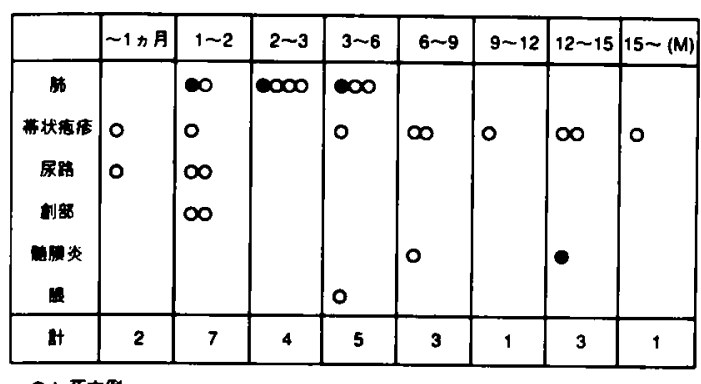

図 2 感染症発症時期

表 4 感染症の病原体

\begin{tabular}{l|c|c|c}
\hline & 生体腎 & 死体監 & 計 \\
\hline Virus & & & \\
Cytomegalovirus & 1 & $2(1)$ & $3(1)$ \\
Herpes zoster & 5 & 4 & 9 \\
Herpes simplex & 1 & 0 & 1 \\
Adenovirus & 3 & 0 & 3 \\
不明 & $1(1)$ & 0 & $1(1)$ \\
Pneumocystis carinii & 2 & $2(1)$ & $4(1)$ \\
細菌 & & & \\
Streptococcus faecalis & 0 & 2 & 2 \\
Listeria & 1 & 0 & 1 \\
真菌 & & & 1 \\
Candida & 0 & 1 & $1(1)$ \\
Aspergillus & 0 & $1(1)$ \\
\hline
\end{tabular}

生回数および発生率は平均 $0.65 \pm 0.90$ 回および

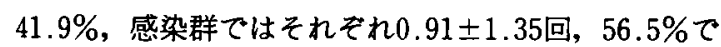
あり, 感染群に多い傾向を認めた（表 5 ).

\section{6）臨床検查值の变動}

感染症は移植後 1 カ月以後に起こっていることよ $\eta$, 感染症発生の予知因子として, 移植前および移植 後14日目, 28日目の白血球数, 血清総蛋白量, 血清乃 ルブミン値, GPT, UN, Cre, IgG, IgM および空腹 時血糖值を比較検討した (図 3〜 5). 感染群では14日 目, 28日目の血清アルブミン值が有意に低下していた. また, 感染群の IgG 値は移植前後で非感染群より高值 であったが, 移植後急速に隇少していた，他には両群 間に有意差を認めなかった。

\section{考 察}

腎移植における術前・術後管理の進歩およびCYA 等の新しい免疫抑制剤の荨入によって，その成䋶は飛 嚾的に向上した.しかし，拒絶反応および感染症は腎 移植の予後を左右する因子として依然解決されていな
表 5 急性拒䋓反応と感染症との戌係

\begin{tabular}{c|c|c}
\hline 急性拒絶反応発生回数 & 非恧染群 & 感 染 群 \\
\hline 0 & 25 & 10 \\
1 & 10 & 10 \\
2 & 6 & 1 \\
3 & 2 & 1 \\
4 & 0 & 0 \\
5 & 0 & 0 \\
6 & 0 & 1 \\
平 均 & $0.65 \pm 0.90$ & $0.91 \pm 1.35$ \\
\hline 急性拒䋓反応発生率 & $18 / 43(41.9 \%)$ & $13 / 23(56.5 \%)$ \\
\hline
\end{tabular}

い. 腎移植臨床登録集計報告》ては， $\mathrm{AZ}$ を用いていた 1982年までとCYA を用いた1983年以降では，敗血症 による死亡率が $28.7 \%$ から $.2 \%$ に著明に減少したが, 肺感染症の比率が $3.5 \%$ から $16.9 \%$, 中でもウイルス性 が0.9\%から5.2\%と增加していると報告されている. これは，AZ は骨髄機能全体を抑制するため汎血球減 少症となりやすく，生体防御能が低下して細菌感染が 大半となり，しかも重篤になりやすいとされ，CYA は ヘルパーT 細胞を比較的選択的に抑制するので，末梢 血の顆粒球数はむしろ多くなり, 細菌感染の頻度が低 下し，ウイルス感染が主流となってきたためと考えら れている3).

感染症発生の背景因子として，ドナーが死体腎であ ることが最も大きな因子であると報告されている゙． われわれの成績では, 感染症発生率には生体堅, 死体 腎による差を認めなかったが，死亡例は死体堅症例に 多かった．年齢に関して，40歳以上で死亡する可能性 が高いとする報告5゙もるが，われわれの成績では中 路らのの報告と同様に有意差を認めなかった。性別で は尿路感染症は女性に多く”，真菌感染症は男性に多 い28 と報告されている.われわれの成績では真菌感染, 尿路感染とも症例数が少なかったが, 男性に感染症が 多かった。術前の透析期間が感染症発生の背景因子と なるという報告6)もあるが，われわれの成績では術前 透析期間, 術前輸血量ともに有意差を認めなかった。

免疫抑制法による感染症発生率は, 敗血症, 膿壊, CMV 感染症などは $\mathrm{AZ}$ 使用群に比べて CYA 使用群 で有意に少ないと報告されているが9)，尿路感染症に 関しては差を認めないとされている 績では $\mathrm{AZ}+\mathrm{PD}$ 群と CYA+PD群では感染症発生頻 度の差はみられなかったが, CYA, AZ, PD の 3 斉併 用群では 2 㶡併用群に比べて有意に頻度が低下してい 

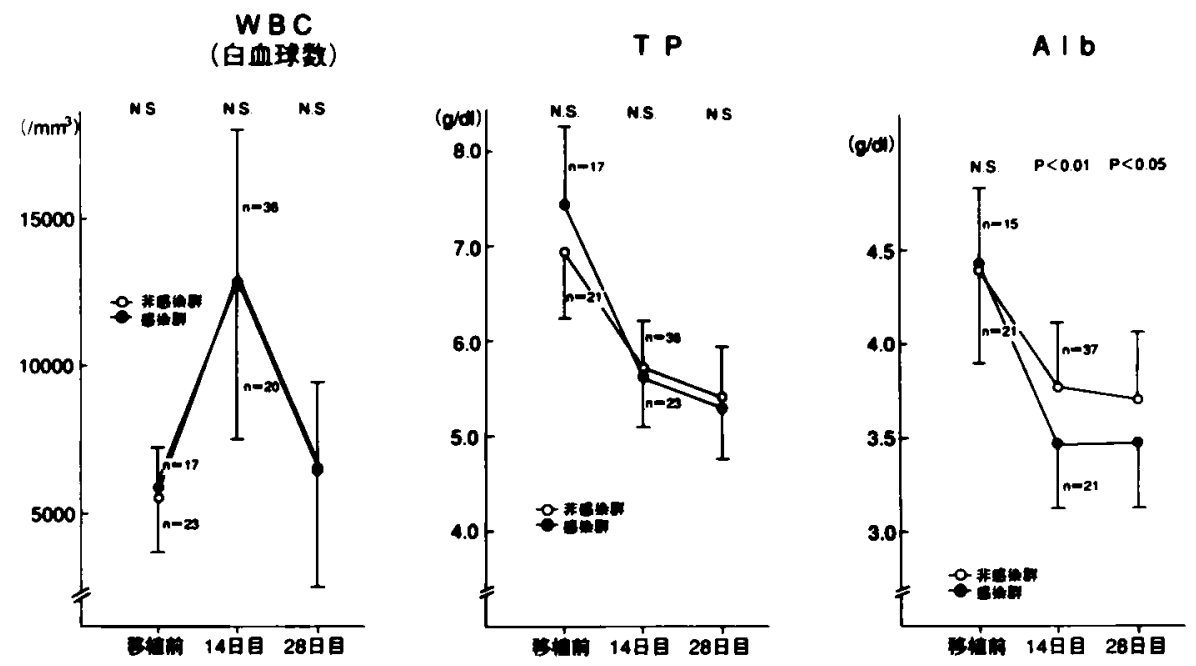

图 3 堅移植前，移植後14日目，28日目の白血球数，血清総蛋白量，血清アルフミン 值
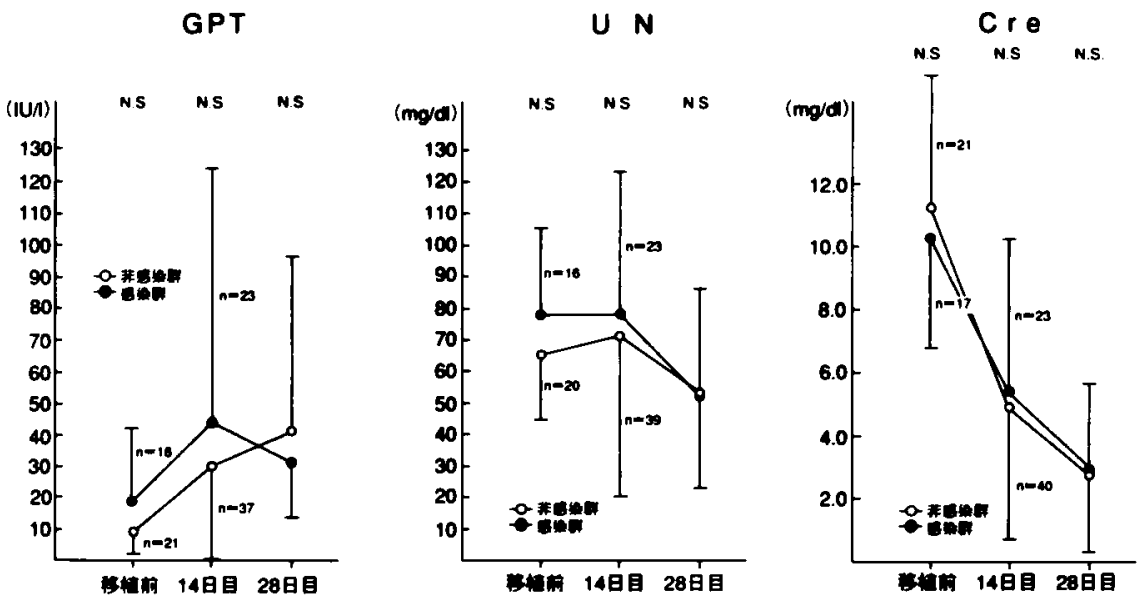

図 4 堅移植前, 移植後14日目，28日目の GPT 值，UN 值，Cre 值

た.この理由として, CYA の血中濃度が高值の場合は 細菌感染が発生しやすく'10), さらにPD 投与総量が多

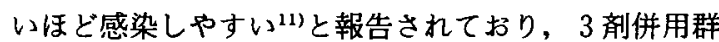
では CYA の血中濃度が低值に抑えられ, PD 投与量も 減量していることによると考えられた。

感染部位として皮周10４6\%，肺10４1\%，尿路 $60 \sim 90 \%$, 創部 $2 \sim 18 \%$, 敗血症 $0 \sim 38 \%$ と報告され ている”が，われわれの成績でも肺，皮局が34.6\%と最 も多かった。

病原体として，腎移植臨床登録集計報告" ${ }^{1}$ と同様に ウイルス感染が $65.4 \%$ と最も多く, PC 15.4\%, 細菌感 染11.5\%, 真菌感染7.7\%であった。
感染症の発症時期は，免疫抑制剂が維持量になるま での移植後数力月以内に発生するという報告が大半で あり, われわれの成䋶でも移植後 1 力月から 6 力月に 多かった。ウイルス感染には 1 定の傾向がみられ, $\mathrm{HSV}$ は移植後 $1 \sim 2$ 力月, CMV は $2 \sim 4$ 力月, HZV は $1 \sim 3$ 力月と 6 力月以降, Adenovirus は 4 力月以 内に発症しやすいと報告されており゙'，これは潜在性 のウイルスが再活性されるのに必要な時期と考えられ た. 細菌による尿路感染症は移植後 1 力月以内に集中 するとされるが"1)，われわれの症例にはみられなかっ た.これは，尿道カテーテルを術後 $3 \sim 4$ 日以内に抜 去し，抗生剤を約 1 週間予防投与すること，さらに約 

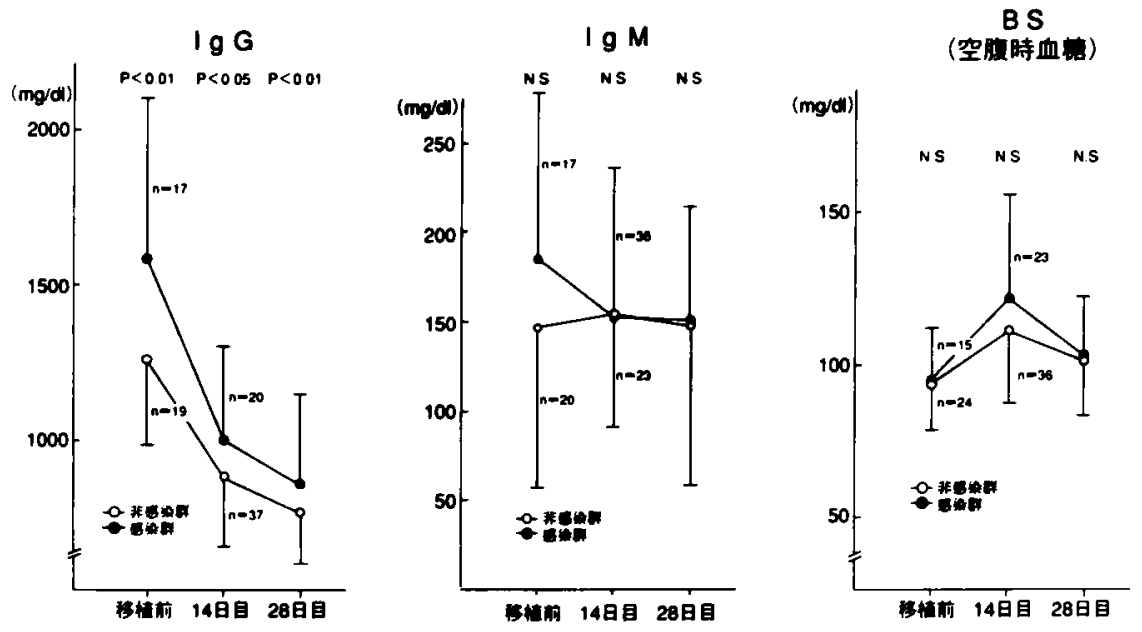

目 5 目移植前，移植後14日目，28日目の IgG 值， IgM 值，空腹時血桾值

1 力月間の病室内清潔操作が影響していると考えられ た。

急性拒絶反応と感染症の関係については関連がない とする報告 ${ }^{22)}$, 密接に関連するという報告 ${ }^{13)}$ がみら れる.われわれの成績では感染群に急性拒絶反応が多 い傾向を認めた。この理由として，移植爼機能の低下 や治療に用いるステロイド剤等の影響が考えられた。

感染症は移植後 1 力月から 6 力月に多く, 1 力月以 内は少ないという結果から, 移植後 1 力月以内の臨床 検査值の変動で感染症発生の予測が可能かどうかを検 討した，栄湌状態，移植腎機能の指標では，血清アル フミン值が感染群で非感染群に比べて有意に低值を示 していた，免疫系の指標では，感染群は移植前の IgG 值が有意に高値であったが, 移植後急速に減少してい た. 中路ら ${ }^{6)}$ 血清総蛋白量, 血清アルブミン值, 免疫 グロブリン值, 空腹時血糖値が感染症発症に関与する 因子であると報告している，腎移植後においては，以 上の結果を考慮に入れた注意深い管理を行うべきであ ると考えられた。

\section{結 語}

1）腎移植66例中23例（35.3\%）に感染症がみられ， 死亡例は死体腎移植症例に多かった。

2）免疫抑制法では, CYA，AZ，PD の 3 郕併用群で 感染症の発生率が低下していた.

3）感染症の発生は, 移植後 1 力月〜 6 力月に多発し ており, 特に尿路感染症に対しては尿道カテーテルの 早期抜去, 抗生剂の予防投与, 病室内清潔操作が効果 的であった。
4）感染群では急性拒絶反応の比率が高かった.

5）移植後14日目, 28日目の臨床検查值では, 感染群 で血清アルブミン值の低下と IgG 值の激減がみられ た。

本論文の要旨は第 30 回日本移植学会総会 (広島)にて発表 した.

また，腎移植に際し御尽力いたたいた滋賀医科大学泌尿 器科友吉唯夫教授, 朴方助教授ならびに井上 均助手 に深甚なる感謝の意を表します.

\section{文献}

1）日本移植学会: 堅移植臨床登録集計報告 (1990). 移植 $26: 494-517,1991$

2）中根佳宏：免疫抑制法はここまで進歩した. 臨透 析 6(Sappl): $79-87,1990$

3) Takahashi K, Yagisawa T, Teraoka $S$, et al : Viral infections in kidney transplant patients immunosuppressed with cyclosporine. Trans. plant Proc 19 : 2142-2149, 1987

4) Burgos-Calderon R, Pankey GA, Figueroa JE : Infection in kidney transplant recipients. Surgery $70: 334-340,1971$

5) Anderson RJ, Schafer LA, Olin DB, et al: Infections risk factors in the immunosuppressed host. Am J Med 54: 453-460, 1973

6）中路啓介，安村忠樹，荒川幸平他：腎移植後感染症 1. 発症に関与する因子. 移植 $28 ： 229-236$, 1993

7) Hamshere RJ, Chisholm BD, Shackman R: Late urinary-tract infection after renal trans- 
plantation. Lancet II : 7884-7885, 1974

8）岡 隆宏, 中根佳宏, 大森吉弘他：腎移植後の真菌 感染症. 移植 $18: 205-210,1983$

9) Canadian Multicenter Transplant Study Group: A randomized clinical trial of cyclosporine in cadaveric renal transplantation. N Engl J Med 309: 809-815, 1983

10）田邉一成, 高橋公太, 東間 紘他: Ciclosporin と 腎移植後尿路感染症．日泌会誌 79：246-253， 1988

11）山本博史：腎移植後感染症の risk factorに関す
る臨床的研究. 京都府医大誌 $92 ： 1033-1049$, 1983

12) Munda $R$, Alexander JW, First MR, et al: Pulmonary infections in renal transplant recipients. Ann Surg 187 : 126-133, 1978

13) Hibberd PL, Tolkoff-Rubin NE, Cosimi AB, et al: Symptomatic cytomegalovirus disease in the cytomegalovirus antibody seropositive renal transplant recipient treated with OKT3. Transplantation 53:68-72, 1992

\title{
A CLINICAL STUDY OF INFECTIONS AFTER RENAL TRANSPLANTATION
}

\author{
Hajime ABE, Hirotaka SAKO, Masashi KODAMA, Koji OKINO* \\ and Yoshihiro NAKANE** \\ First Department of Surgery, Shiga University of Medical Science \\ *Department of Surgery, Tohjinkai Hospital \\ - Department of Surgery, Ohmihachiman Municipal Hospital
}

A clinical study of infections was made of 66 patients undergoing renal transplantation from 33 living related donors and 33 cadaveric donors at our institute from July 1982 to June 1994 . Twenty-six episodes of infection occurred in 23 patients. Infections occurred in 5 cases out of 11 patients treated with azathioprine (AZ) and prednisolone (PD), 9 cases out of 22 treated with ciclosporin (CYA) and PD, and 9 cases out of 33 treated with CYA, AZ and PD. There occurred 9 episodes of pulmonary infection, 9 episodes of herpes zoster, 2 episodes of meningitis, 3 episodes of hemorrhagic cystitis, and one episode of conjunctivitis, including viral infection in 17, pneumocystic carinii in 4, bacterial infection in 3 and fungal infection in 2 cases. Four patients died of infection. Seventeen episodes occurred from 1 to 6 months after renal transplantation. Cadaveric donor was relatively associated with infectious death, and acute rejection was also relatively associated with infections. The significant differences were observed in the levels of albumin and IgG between infectious and non-infectious patients. In conclusion, infections after renal transplantation would be associated with the dose of $\mathrm{PD}$ and acute rejection, and the levels of albumin and IgG could be predicting factors of infection. 